Article

\title{
Influence of the Bronsted Acidity on the Ring Opening of Decalin for Pt-USY Catalysts
}

\author{
Lech Walesa Oliveira Soares * (1) and Sibele Berenice Castellã Pergher \\ Instituto de Química, Laboratório de Peneiras Moleculares (LABPEMOL), Universidade Federal do Rio Grande \\ do Norte, Natal 59078-970, RN, Brazil; sibelepergher@gmail.com \\ * Correspondence: lechsoares@gmail.com; Tel.: +55-8499-645-3533
}

Received: 5 August 2019; Accepted: 21 August 2019; Published: 20 September 2019

check for updates

\begin{abstract}
A challenging hot topic faced by the oil refinery industry is the upgrading of low-quality distillate fractions, such as light cycle oil (LCO), in order to meet current quality standards for diesel fuels. An auspicious technological alternative entails the complete saturation of the aromatic structures followed by the selective cleavage of endocyclic carbon-carbon bonds in the formed naphthenic rings (selective ring opening-SRO). This work reports the influence of Brønsted acid sites of platinum-ultra stable Y zeolite (Pt-USY) catalysts in the SRO of decalin as a model naphthenic feed. A maximum combined yield to selective ring opening products (ROP: C10-alkylcycloalkanes + OCD: C10-alkanes) as high as $28.6 \mathrm{wt} \%$ was achieved for $1.6 \mathrm{Pt}-\mathrm{NaUSY}$-im catalyst. The molar carbon distribution curve of the hydrocracked $\left(\mathrm{C}_{9-}\right)$ products varied from M-shaped for 1.4Pt-USY-im catalyst, indicating mainly $\mathrm{C}-\mathrm{C}$ bond cleavage of the ring opening products with one remaining naphthenic ring via carbocations and the paring reaction, to not $\mathrm{M}$-shaped for the $1.6 \mathrm{Pt}-\mathrm{NaUSY}$-im catalyst, where carbon-carbon bond cleavage occurs preferentially through a hydrogenolysis mechanism on metal sites. High (hydro)thermal stability and secondary mesoporosity of the 1.6Pt-NaUSY-im catalysts make this system highly prospective for upgrading low-quality real distillate feeds.
\end{abstract}

Keywords: ring opening; decalin; Pt-USY catalysts; Brønsted acidity

\section{Introduction}

The presence of polynuclear aromatic hydrocarbons (PAHs) in refinery streams, such as light cycle oil (LCO) abundantly produced in fluid catalytic cracking (FCC) and middle distillates from cockers or coming from bitumen-derived synthetic crude oils, make it unfeasible to be blended with commercial diesel or jet fuels, which is a problem to certain refineries. The problem will aggravate, as more and more heavy crude oils with high aromatics content will have to be processed in the future. PAHs are not suitable as components of diesel fuel fractions as they present some drawbacks, such as: (i) very low cetane number (CN), (ii) unfavorable cold-flow properties, (iii) a too high density of the fuel, (iv) they are precursors of soot and particulate matter in tail gas, (v) poor ignition characteristics, and (vi) their low hydrogen content brings about relatively high $\mathrm{CO}_{2}$ emissions per heating value.

Hence, increasingly stringent standards regarding the quality of transport fuels are continuously being implemented in developed economies with the aim of mitigating the detrimental impact of the exhaust emissions on the environment as well as on human health, particularly in the most populated areas. Current requirements for diesel in the European Union, covered by EN 590, include a minimum $\mathrm{CN}$ of 51 , a maximum concentration of PAHs of $8 \mathrm{wt} \%$, and a sulfur content of 10 ppm maximum. In the United States a sulfur limit of 15 ppm and a minimum $\mathrm{CN}$ of 41 have been efficiently applied since 2010 for ultra-low sulfur diesel (ULSD) for highway use, while a maximum aromatic content of $10 \mathrm{wt} \%$ is allowed in certain states like California [1]. 
A promising industrial solution to overcome the issue of PAHs in some refinery streams is based on a two-stage catalytic process. First, the aromatics are hydrotreated/hydrogenated to saturated naphthenes (aromatic saturation-ASAT) [2,3]. Second, the formed naphthenes undergo selective ring opening (SRO), ideally to the linear paraffin with the same number of carbon atoms as the original aromatic hydrocarbon [3]. This catalytic process occurs with an increase in the cetane number. The CN of hydrocarbons is closely related to their molecular structure. As a general trend, for hydrocarbons with a given number of carbon atoms the $\mathrm{CN}$ increases in the following order: (poly)aromatics < naphthenes $<$ iso-paraffins $<$ n-paraffins. Thus, ideally converting aromatics into linear paraffins would produce the highest achievable increase in $\mathrm{CN}$, starting from low-quality highly-aromatic refining fraction. As an additional advantage, SRO increases the volume of available for selling due to the gradual decrease in density when going from the aromatic to the corresponding paraffin.

Three main families of solid catalysts are usually distinguished for the cleavage of carbon-carbon bonds, viz. (i) monofunctional acid catalysts, mostly faujasites and beta, [4,5]; (ii) monofunctional metal catalysts; and (iii) bifunctional catalysts containing both Bronsted and metal sites $[5,6]$.

Monofunctional acidic catalysts are inappropriate for the ring opening of decalin because they undergo deactivation due to coking, significant amounts of light hydrocarbons and hydrocarbons with more than 10 carbon atoms are formed at elevated conversions, and the yields of ring opening products are unacceptably low, generally about $10 \%$ at most $[4,5,7]$. The chemistry of the ring opening on such catalysts proceeds via carbocation, either by classical $\beta$-section or through direct protolytic cracking at a tertiary carbon atom of decalin.

The ring opening of naphthenic compounds on monofunctional metallic catalysts occurs via hydrogenolysis of endocyclic carbon-carbon bonds through three different mechanisms [8]. First, the non-selective (multiplet) mechanism proceeding on highly-dispersed platinum presents an equal probability for cleavage either secondary-secondary, secondary-tertiary, or tertiary-tertiary carbon-carbon bonds through flat adsorption, resulting in statistical product distribution. Second, the selective (dicarbene or doublet) mechanism occurring on poorly-dispersed platinum and on iridium and rhodium catalysts, irrespective of metal particle size breaking unsubstituted secondary carbon-carbon bonds exclusively through perpendicular adsorption, resulting in the preferential formation of less desired highly branched paraffins. Third, the partially selective (or metallacyclobutane) mechanism competing with the selective mechanism in cases when at least one carbon atom is substituted by a methyl group. In a nutshell, products of SRO (i.e., paraffins less branched) from catalysts with well-dispersed $\mathrm{Pt}$ are the most desired because they present high $\mathrm{CN}$, which is a key parameter concerning diesel fuel.

Bifunctional catalysts comprised of a noble metal with high hydrogenolysis activity (Pt, Ir) dispersed on large pore zeolites (i.e., faujasites and beta) are among the most prospective so far developed for the SRO reaction [1]. For these catalysts, low density of Brønsted acid sites and very high metal dispersion $(>80 \%)$ at high metal loading $(\geq 3 \mathrm{wt} \%)$ are the main requirements to achieve high yields to SRO products by promoting opening of the naphthenic rings via hydrogenolysis on the metal centers, while minimizing unwanted acid-catalyzed secondary cracking of SRO products into lighter hydrocarbons. Some Brønsted acidity; however, is still needed to catalyze the $\mathrm{C}_{6}$-to- $\mathrm{C}_{5}$ ring contraction in the naphthenes to facilitate the subsequent SRO on the metal function. These features are accomplished by the so-coined HIPEROC (high performance ring opening catalyst) systems, in where the metal ( $\mathrm{Pt}$, Ir or combinations thereof) is incorporated in very high dispersion $(>80 \%)$ via ionic exchange on Al-rich low-acidic NaX/NaY zeolites, on which yields of SRO products above $40 \%$, particularly to the so-called open-chain decanes (OCDs) with highest cetane, were achieved starting from a model decalin feed [9].

Although, theoretically, SRO is a promising route for upgrading low-value feeds to high-quality products, in practice, it continues to be a challenge owing to its complex chemistry. Product characteristics depend not only on the composition of the feed but also on the operating conditions and the nature of the catalyst. Research on SRO has long been carried out on model hydrocarbons 
consisting of single-ring naphthenic compounds, such as methylcyclopentane [10,11], cyclohexane [12], and methylcyclohexane [13-15]. The advantage of using these molecules is the small number of products, which facilitates the interpretation of reaction mechanisms. However, these compounds are poor representatives of the LCO composition. To account for this limitation, two-ring probe molecules, such as decalin and tetralin, have been employed [5,13,16-27]. However, even by starting from a single molecule (or two stereoisomers in the case of decalin), a complex mixture of ca. 200 hydrocarbons is formed upon reaction on bifunctional catalysts, because of the variety of reaction steps occurring on metal and/or acid sites. In this context, full separation and identification of the molecules are difficult tasks. One-dimensional gas chromatography (GC) using a 150-capillary column, coupled with mass spectrometry (MS), permitted one to tentatively identify 200 compounds and classify the products into several families. However, possible coelution, along with incomplete MS databases, lead to identification uncertainties, making the use of comprehensive two-dimensional gas chromatography $(\mathrm{GC} \times \mathrm{GC})$ indispensable $[17,28,29]$.

Low (hydro)thermal stability, related to the high $\mathrm{Al}$ content in the framework of $\mathrm{NaX} / \mathrm{NaY}$ zeolites, and hampered diffusion of bulky naphthenes (and corresponding SRO products) typically present in real feeds in these purely microporous zeolites; however, may impair their potential industrial implementation. To overcome these drawbacks, we here alternatively propose the use of more robust, high Si/Al ratio ultra stable Y (USY) zeolite as the acid carrier in bifunctional Pt-containing SRO catalysts. To this aim, in this study we report the influence of the Brønsted acidity of bifunctional Pt-USY catalysts and their catalytic performance for SRO of decalin.

\section{Results and Discussion}

\subsection{Characterization of Catalysts}

Figure 1 shows the diffractograms of the USY and sodium type USY zeolite (NaUSY) zeolitic supports and their catalysts 1.4Pt-USY-im and 1.6Pt-NaUSY-im. It reveals that the materials present the typical reflexes of faujasite. No reflexes of the most likely impurity (i.e., zeolite A) are visible. Table 1 presents the relative crystallinity of the NaUSY sample and Pt-NaUSY catalysts which were calculated by comparing the area of the diffraction peaks at ca. $2 \theta=20^{\circ}$ and $2 \theta=24^{\circ}$ with that of the commercial USY sample (assuming CBV760, 100\% crystallinity) and the materials (NaUSY, 1.4Pt-USY-im and 1.6Pt-NaUSY-im) preserve the crystallinity of USY zeolite.

The main physicochemical and metallic function properties of the bare zeolites (USY, NaUSY) and the Pt-USY catalysts are summarized in Table 1 and the textural properties in Table 2. The Si:Al ratio increases from USY to NaUSY due to the $\mathrm{pH}$ of the ion exchange with sodium nitrate $0.1 \mathrm{~mol} / \mathrm{L}$ being slightly acidic ( $\mathrm{pH} \sim 6.0$ ), resulting in a partial dealumination of USY. The method used to reduce the amount of Brønsted acidic sites (BAS) of USY zeolite was efficient (Table 3). For example, at $250{ }^{\circ} \mathrm{C}$ the reduction was from 67.7 (USY) to $18.7 \mu \mathrm{mol} / \mathrm{g}$ (NaUSY) of desorbed pyridine and from 68.2 to $22.2 \mu \mathrm{mol} / \mathrm{g}$ of desorbed pyridine for 1.4Pt-USY-im and 1.6Pt-NaUSY-im catalysts, respectively. This method consists of exchanging protons $\left(\mathrm{H}^{+}\right)$for sodium ions $\left(\mathrm{Na}^{+}\right)$, charge compensating cations, where the amount of sodium ions increased from 0.02 (USY) to $0.39 \mathrm{wt} \%$ (NaUSY). These values remained constant for their respective catalysts. It is seen in Table 1 that the metal content of the catalysts is nearly the nominal content of $1.5 \mathrm{wt} \%$. The metal dispersions of the bifunctional catalysts as measured by hydrogen chemisorption varies from $21.4 \%$ to $27.7 \%$. This difference is considered not relevant. The active metal surface area (AMSA) and the mean diameter of platinum nanoparticles $\left(\mathrm{d}_{\mathrm{Pt}}\right)$ are also presented in Table 1, in which the 1.6Pt-NaUSY-im catalyst presented higher AMSA and lower mean diameter of platinum nanoparticles compared to the 1.4Pt-USY-im catalyst.

The textural properties of the USY, NaUSY, and platinum-containing zeolite catalyst are presented in Table 2. After each treatment in the bare USY zeolite, the surface area $\left(\mathrm{S}_{\mathrm{BET}}\right)$ and the micropore volume $\left(\mathrm{V}_{\text {micro }}\right)$ decrease proportionally to the incorporation of platinum into the catalysts. The mesoporous 
area $\left(\mathrm{S}_{\text {meso }}\right)$, mesoporous volume $\left(\mathrm{V}_{\text {meso }}\right)$, and total pore volume (TPV) of NaUSY and Pt-USY catalysts were practically kept constant compared to the bare USY zeolite.

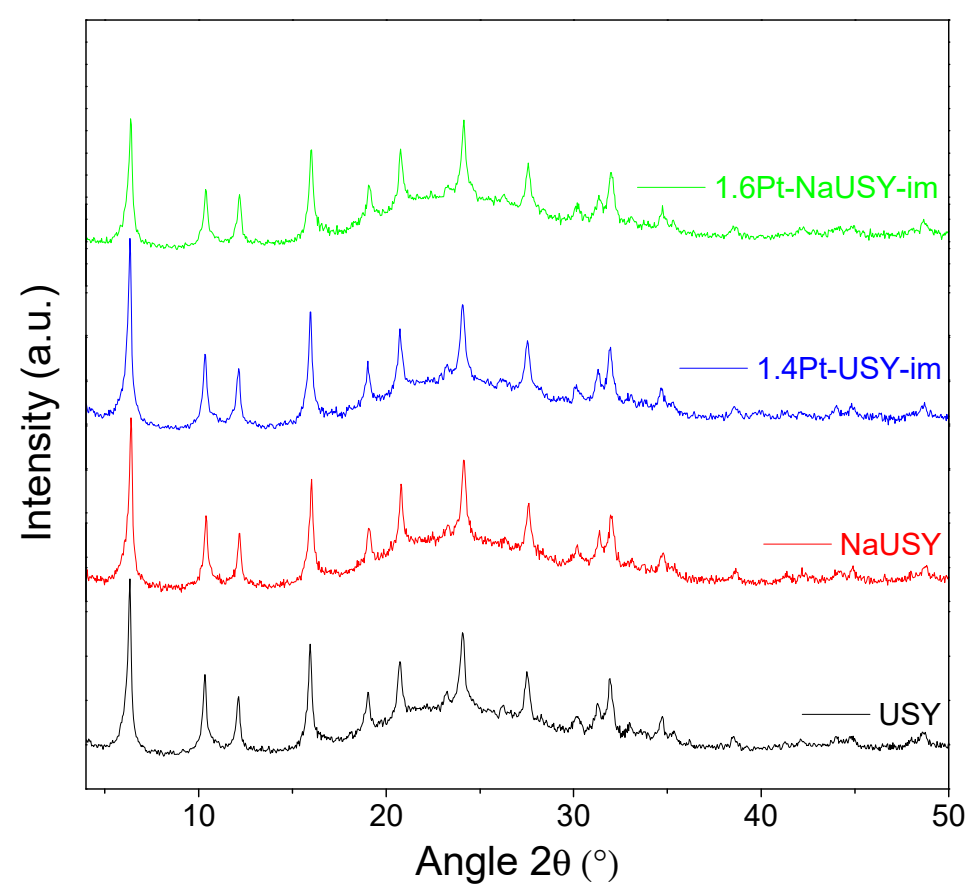

Figure 1. X-ray diffractogram of USY and NaUSY zeolites and 1.4Pt-USY-im and 1.6Pt-NaUSY-im catalysts.

Table 1. Physicochemical and metallic function properties of USY and NaUSY zeolites and 1.4Pt-USY-im and 1.6Pt-NaUSY-im catalysts.

\begin{tabular}{|c|c|c|c|c|c|c|c|}
\hline Zeolite & $\mathrm{Si}: \mathrm{Al}^{\mathrm{a}}$ & $\mathrm{Na}^{\mathrm{b}}(\mathrm{wt} \%)$ & Cryst. $^{\mathrm{c}}(\%)$ & $\mathrm{Pt}^{\mathrm{d}}(\mathrm{wt} \%)$ & $D_{P t}{ }^{e}(\%)$ & $\operatorname{AMSA}^{\mathrm{f}}\left(\mathrm{m}^{2} / \mathrm{g}\right)$ & $d_{P t} g(n m)$ \\
\hline USY & 26.5 & 0.02 & 100 & & & & \\
\hline NaUSY & 27.0 & 0.39 & 99 & & & & \\
\hline 1.4Pt-USY-im & 26.0 & 0.02 & 96 & 1.4 & 21.4 & 0.8 & 5.28 \\
\hline 1.6Pt-NaUSY-im & 27.0 & 0.39 & 92 & 1.6 & 27.7 & 1.1 & 4.08 \\
\hline
\end{tabular}

${ }^{a} \mathrm{Si}: \mathrm{Al}$ ratio measured by inductively coupled plasma optical emission spectrometry (ICP-OES). ${ }^{\mathrm{b}} \mathrm{Na} \mathrm{wt} \%$ (weight percent) measured by ICP-OES. ${ }^{c}$ Relative crystallinity determined by diffractogram calculations. ${ }^{\mathrm{d}}$ Platinum loading measured by ICP-OES. ${ }^{e}$ Platinum dispersion derived from $\mathrm{H}_{2}$ chemisorption. ${ }^{\mathrm{f}}$ Active metal surface area calculated from $\mathrm{H}_{2}$ chemisorption. ${ }^{g}$ Mean diameter of $\mathrm{Pt}$ nanoparticles derived from $\mathrm{H}_{2}$ chemisorption experiments.

Table 2. Textural properties of USY and NaUSY zeolites and 1.4Pt-USY-im and 1.6Pt-NaUSY-im catalysts.

\begin{tabular}{cccccc}
\hline Zeolite & $\mathbf{S}_{\text {BET }}\left(\mathbf{m}^{2} / \mathbf{g}\right)$ & $\mathbf{S}_{\text {meso }}{ }^{\mathbf{a}}\left(\mathbf{m}^{2} / \mathbf{g}\right)$ & $\mathbf{V}_{\text {micro }}{ }^{\mathbf{b}}\left(\mathbf{c m}^{\mathbf{3}} / \mathbf{g}\right)$ & $\mathbf{T P V}^{\mathbf{c}}\left(\mathbf{c m}^{3} / \mathbf{g}\right)$ & $\mathbf{V}_{\text {meso }}{ }^{\mathbf{d}}\left(\mathbf{c m}^{\mathbf{3}} / \mathbf{g}\right)$ \\
\hline USY & 514.4 & 86.0 & 0.217 & 0.447 & 0.230 \\
NaUSY & 499.3 & 86.4 & 0.208 & 0.469 & 0.261 \\
1.4Pt-USY-im & 483.9 & 88.4 & 0.200 & 0.474 & 0.274 \\
1.6Pt-NaUSY-im & 465.3 & 85.5 & 0.191 & 0.457 & 0.266 \\
\hline
\end{tabular}

${ }^{a}$ Mesoporous area determined from $S_{\text {meso }}=S_{B E T}-S_{\text {micro }}$, where $S_{\text {micro }}$ is the microporous area calculated from t-plot analysis of $\mathrm{N}_{2}$ adsorption isotherm. ${ }^{\mathrm{b}}$ Volume of micropores derived from the t-plot analysis of the $\mathrm{N}_{2}$ adsorption isotherm. ${ }^{\mathrm{c}}$ Total pore volume determined from the point where $\mathrm{P} / \mathrm{P} 0=0.99$. ${ }^{\mathrm{d}}$ Volume of mesoporous determined by the equation $V_{\text {meso }}=T P V-V_{\text {micro }}$. 
Table 3. Density of Brønsted acid sites ( $\mu \mathrm{mol} / \mathrm{g}$ ) determined by FTIR spectroscopy of adsorbed pyridine at 250,350 , and $400{ }^{\circ} \mathrm{C}$.

\begin{tabular}{cccc}
\hline Zeolite & \multicolumn{3}{c}{ Brønsted } \\
\hline USY & $250{ }^{\circ} \mathrm{C}$ & $350{ }^{\circ} \mathrm{C}$ & $400{ }^{\circ} \mathrm{C}$ \\
NaUSY & 67.7 & 28.0 & 4.7 \\
1.4Pt-USY-im & 18.7 & 3.5 & 1.2 \\
1.6Pt-NaUSY-im & 68.2 & 29.2 & 10.5 \\
\hline
\end{tabular}

\subsection{Catalytic Results}

The conversion of decalin is depicted in Figure 2 as a function of reaction temperature for the studied 1.4 Pt-USY-im and 1.6 Pt-NaUSY-im catalysts. No deactivation was observed for any of the Pt-USY catalysts at the reaction conditions employed in this work. For both catalysts, the conversion of decalin was comprised in a temperature range from 300 to $390^{\circ} \mathrm{C}$ for a complete decalin hydroconversion. The activity difference is very pronounced between the catalyst 1.4Pt-USY-im with a higher amount and stronger Brønsted acidity compared to catalyst 1.6Pt-NaUSY-im. The order of activity is $1.4 \mathrm{Pt}$-USY-im $>1.6 \mathrm{Pt}$-NaUSY-im. The higher activity of the $1.4 \mathrm{Pt}$-USY-im catalyst can be ascribed to its much higher amount of BAS (see Table 3). Then, it can be stated that the conversion of decalin at the studied conditions is mostly driven by the Brønsted acidity for the catalyst 1.4Pt-USY-im and via hydrogenolysis on metallic sites for 1.6Pt-NaUSY-im.

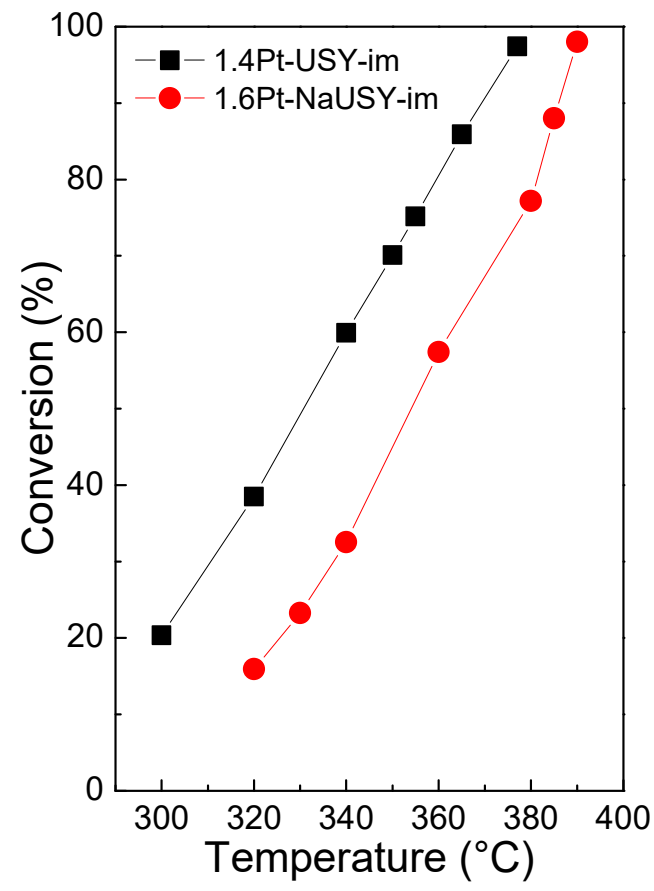

Figure 2. Decalin conversion (\%) vs. reaction temperature $\left({ }^{\circ} \mathrm{C}\right)$ obtained for $1.4 \mathrm{Pt}$-USY-im and 1.6Pt-NaUSY-im catalysts. Reaction conditions: $\mathrm{T}=300-390{ }^{\circ} \mathrm{C}$, Weight hourly space velocity $($ WHSV $)=3.22 \mathrm{~h}^{-1}$, Pressure $(\mathrm{P})=35$ bar, and molar ratio hydrogen/decalin $\left(\mathrm{H}_{2} / \mathrm{D}\right)=100$.

As well as in catalytic activity, there are considerable differences with respect to the product selectivities and yields for the catalysts studied (Figures 3 and 4). Throughout the decalin conversion range, the 1.4Pt-USY-im catalyst presents higher yield and selectivity to the decalin isomer (IsoD) than the 1.6Pt-NaUSY-im catalyst. As the amount of the Bronsted acid sites is further reduced with increasing temperature, the degree of skeletal isomerization reduces, because they are more and more consumed in consecutive reactions leading to $\mathrm{ROP}, \mathrm{OCD}$, and undesired $\mathrm{C}_{9-}$ - hydrocarbons. 
The formation of skeletal isomers on the Pt-USY catalysts must, hence, be ascribed to a bifunctional pathway via carbocations on the Bronsted acid sites and on platinum. For both catalysts, the decalin isomers (IsoD) are the main products but in different levels of extent.
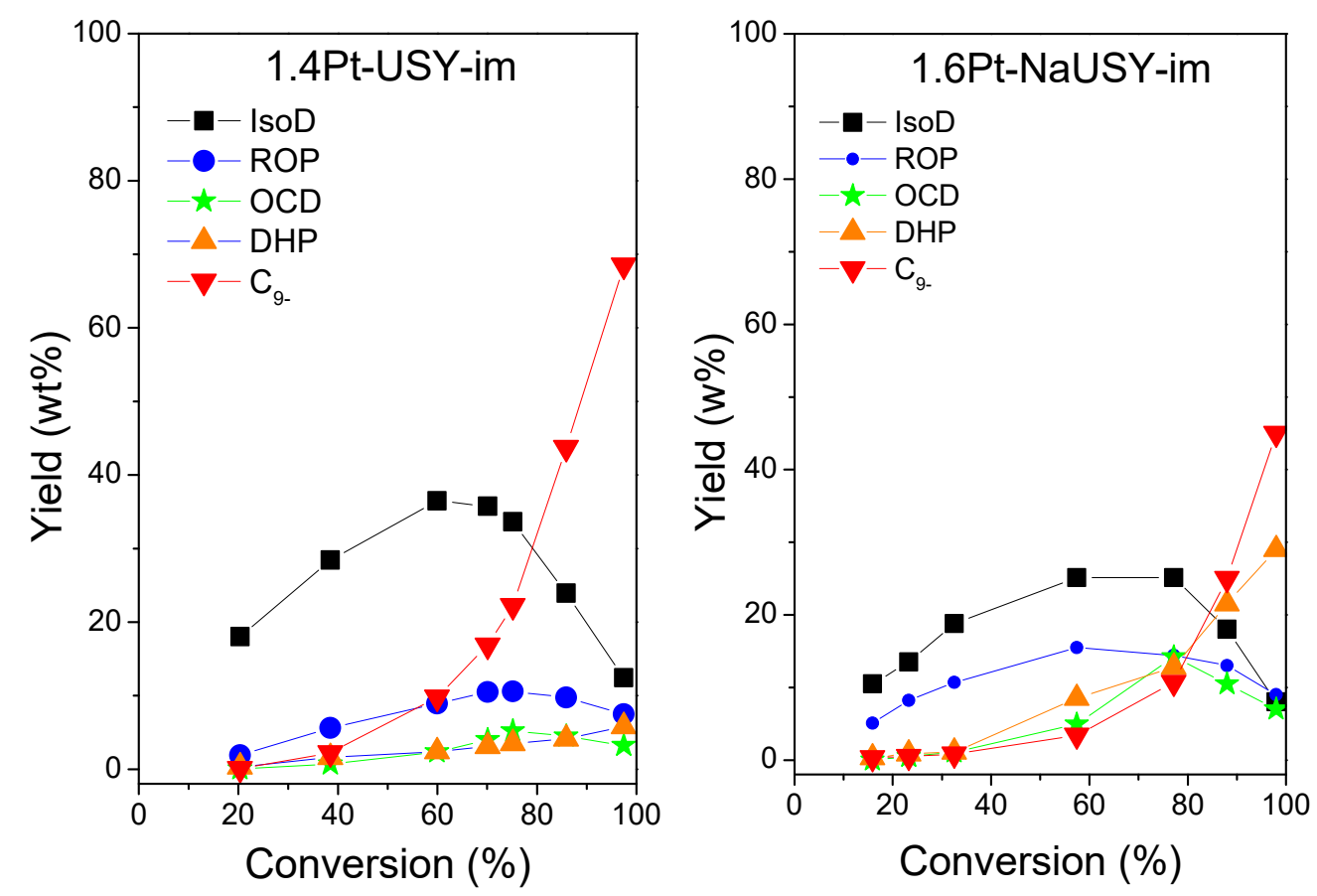

Figure 3. Product yields (wt $\%$ ) vs. decalin conversion (\%) obtained for 1.4Pt-USY-im and 1.6Pt-NaUSY-im catalysts. Reaction conditions: $\mathrm{T}=300-390{ }^{\circ} \mathrm{C}, \mathrm{WHSV}=3.22 \mathrm{~h}^{-1}, \mathrm{P}=35 \mathrm{bar}$, and $\mathrm{H}_{2} / \mathrm{D}=100$.
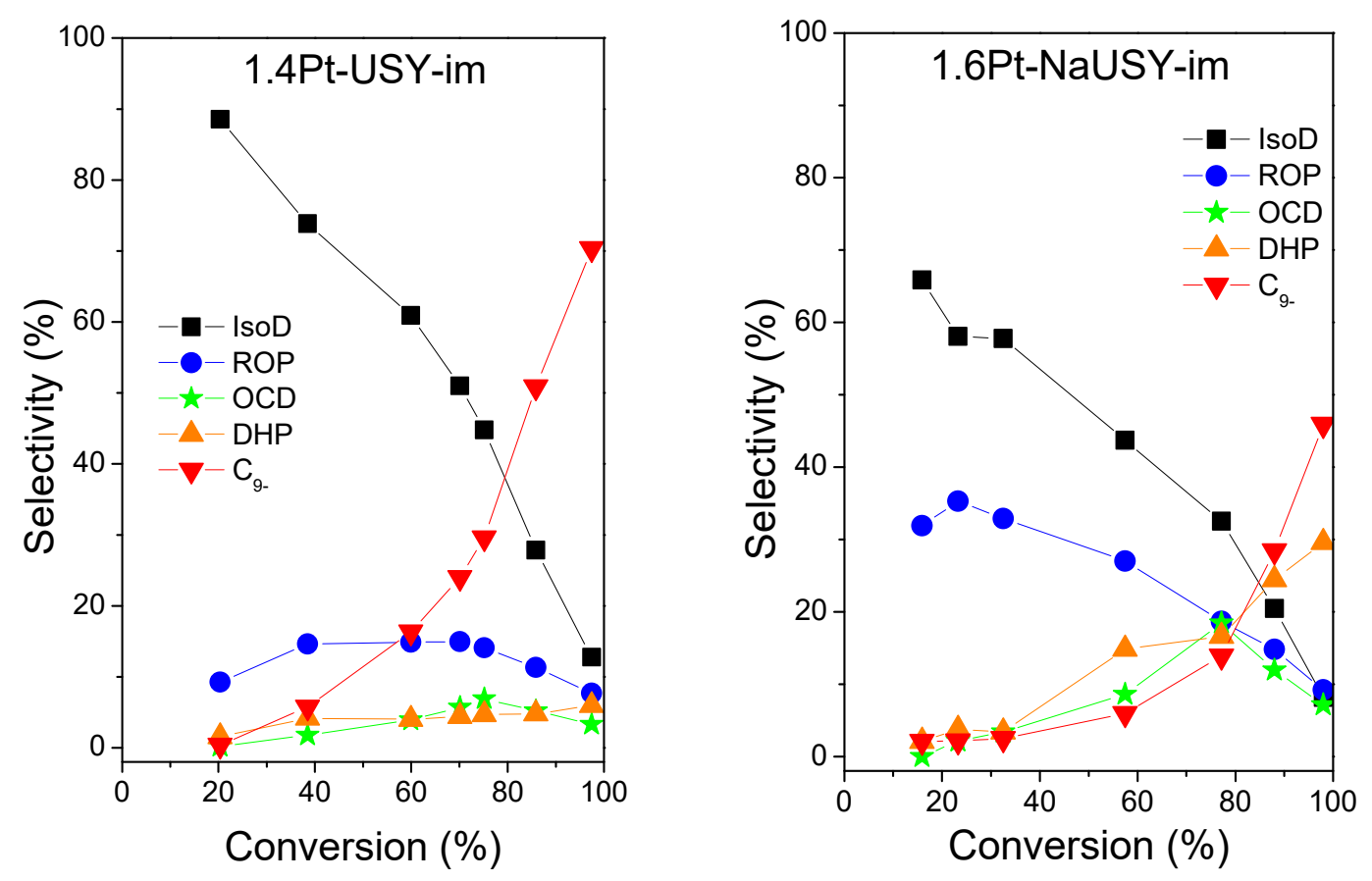

Figure 4. Product selectivities (\%) vs. decalin conversion (\%) obtained for 1.4Pt-USY-im and 1.6Pt-NaUSY-im catalysts. Reaction conditions: $\mathrm{T}=300-390^{\circ} \mathrm{C}, \mathrm{WHSV}=3.22 \mathrm{~h}^{-1}, \mathrm{P}=35 \mathrm{bar}$, and $\mathrm{H}_{2} / \mathrm{D}=100$.

Figures 4 and 5 show that for both catalysts studied, as the temperature is increased, the yield and selectivity of OCDs increase noticeably, and it passes through a maximum because all $C_{10}$ hydrocarbons 
are eventually consumed by hydrocracking to $\mathrm{C}_{9-}$. The heights of the maxima in $\mathrm{R}_{\mathrm{OCDs}}$ are 5.2 and $14.2 \mathrm{wt} \%$ for 1.4Pt-USY-im and 1.6Pt-NaUSY-im, respectively (see Table 4). The heights of the maxima in $\mathrm{S}_{\mathrm{OCDs}}$ are $6.9 \%$ and $18.4 \%$ for 1.4Pt-USY-im and 1.6Pt-NaUSY-im, respectively (see Table 5). The amount of $\mathrm{C}_{9-}$ hydrocracking products increases exponentially for both catalysts when decalin conversion is ca. $80 \%$. The yield and selectivity of dehydrogenated products (DHP) are higher for the 1.4Pt-USY-im catalyst than for the 1.6Pt-NaUSY-im catalyst because that requires higher temperatures for decalin hydroconversion when compared to this, and at higher temperatures dehydrogenation of hydrocarbons on platinum metal sites is favored.

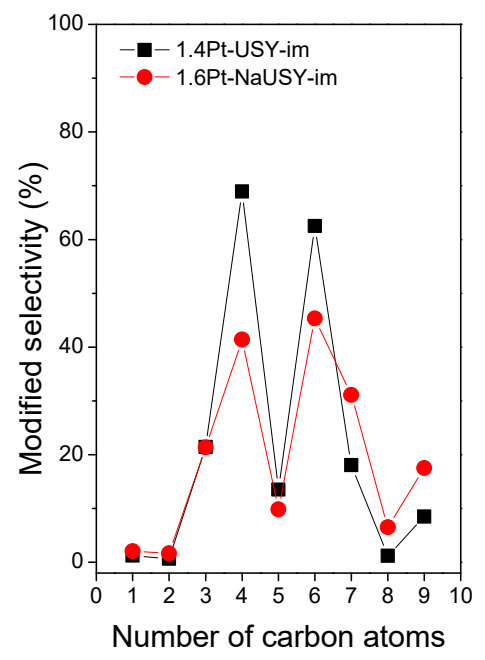

Figure 5. Modified hydrocracking selectivity (\%) obtained at a constant cracking yield ( $\left.\mathrm{C}_{9-} \sim 20 \mathrm{wt} \%\right)$ for 1.4Pt-USY-im and 1.6Pt-NaUSY-im catalysts. Reaction conditions: $\mathrm{P}=35 \mathrm{bar}, \mathrm{H}_{2} / \mathrm{D}=100$, and WHSV $=3.22 \mathrm{~h}^{-1}$.

Table 4. Maximum yields of OCDs obtained for 1.4Pt-USY-im and 1.6Pt-NaUSY-im catalysts.

\begin{tabular}{|c|c|c|c|c|c|c|}
\hline Catalysts & $\mathrm{T}\left({ }^{\circ} \mathrm{C}\right)$ & $X_{D}{ }^{a}(\%)$ & $\mathrm{R}_{\mathrm{ROPs}}(\mathrm{wt} \%)$ & $\mathrm{R}_{\mathrm{OCDs} \text {, máx }}(w \mathrm{t} \%)$ & $\mathrm{R}_{\mathrm{ROPs}}+\mathrm{R}_{\mathrm{OCDs}}(\mathrm{wt} \%)$ & $R_{C_{9-}}(w t \%)$ \\
\hline 1.4Pt-USY-im & 355 & 75.1 & 10.6 & 5.2 & 15.7 & 22.2 \\
\hline 1.6Pt-NaUSY-im & 380 & 77.2 & 14.4 & 14.2 & 28.6 & 10.7 \\
\hline
\end{tabular}

a decalin conversion

Table 5. Maximum selectivities of OCDs obtained for 1.4Pt-USY-im and 1.6Pt-NaUSY-im catalysts.

\begin{tabular}{lcccccc}
\hline \multicolumn{1}{c}{ Catalysts } & $\mathbf{T}\left({ }^{\circ} \mathbf{C}\right)$ & $\mathbf{X}_{\mathbf{D}}(\mathbf{\%})$ & $\mathbf{S}_{\mathbf{R O P s}}(\%)$ & $\mathbf{S}_{\mathbf{O C D s}, \max }(\%)$ & $\mathbf{S}_{\mathbf{R O P s}}+\mathbf{S}_{\text {OCDs }}(\%)$ & $\boldsymbol{R}_{\boldsymbol{C}_{9-}}(\mathbf{w t} \%)$ \\
\hline 1.4Pt-USY-im & 355 & 75.1 & 14.1 & 6.9 & 21 & 29.6 \\
1.6Pt-NaUSY-im & 380 & 77.2 & 18.7 & 18.4 & 37.1 & 13.9 \\
\hline
\end{tabular}

From a commercial point of view, the yields of the highly desired OCDs are even more relevant than their selectivities. In Table 4, the maximum yields of OCDS for both Pt-USY catalysts are listed. Bearing in mind that the ring opening products with one remaining naphthenic ring are desired components of diesel fuel as well, the sum of the yields of ROPs and OCDs are given in Table 4. In summary, based on the results of products yield and product selectivities to ROPs and OCDs, it can be stated that the catalyst 1.6Pt-NaUSY-im presented the best results, which are a yield of $28.6 \mathrm{wt} \%$ and a respective selectivity of $37.1 \%$ to the sum of ROPs and OCDs. The last column of Table 4 reveals that, at the maximum yields of OCDs, the 1.6Pt-NaUSY-im catalyst gives the lowest yield of the undesired hydrocracked products ca. $10.7 \mathrm{wt} \%$, while the $1.4 \mathrm{Pt}$-USY-im presents yield of ca. $22.2 \mathrm{wt} \%$.

A detailed analysis of the carbon number distribution in the $\mathrm{C}_{9-}$ fraction was performed in order to obtain qualitative information about the relative contribution of the hydrogenolysis (on the metal) 
and $\beta$-scission (on BAS) mechanisms to the breaking of $\mathrm{C}-\mathrm{C}$ bonds leading to both ring opening and cracking products. To this purpose, the light products selectivity (in \%), defined as the number of moles of hydrocarbons with " $x$ " carbon atoms formed divided by the moles of decalin converted into cracked products, was calculated for each catalyst and presented in Figure 5 for representative catalysts.

It is considered that $C_{1}$ and $C_{9}$ hydrocarbons can only form through the hydrogenolysis pathway as their formation via acid catalysis ( $\beta$-scission) would involve energetically unfavorable primary carbocations. Taking this into account, a prevailing acid mechanism is inferred for the 1.4Pt-USY-im catalyst at the view of the M-type distribution curve in the $C_{3}-C_{7}$ region, with sharp maxima at $C_{4}$ and $\mathrm{C}_{6}$. Such $\mathrm{M}$-shaped carbon-number distribution is characteristic for the paring reaction leading mainly to iso-butane and methylcyclopentane [25]. Conversely, the higher selectivity to $C_{9}$ hydrocarbons and the flatter distribution in the $\mathrm{C}_{3}-\mathrm{C}_{7}$ range observed in Figure 5 for the 1.6Pt-NaUSY-im catalyst are indicative of a significant contribution of the metal-catalyzed hydrogenolysis pathway to the cleavage of $\mathrm{C}-\mathrm{C}$ bonds. For instance, the $1.4 \mathrm{Pt}$-USY-im catalyst presented higher selectivity to $\mathrm{C}_{4}(69 \%)$ and $\mathrm{C}_{6}(62 \%)$ hydrocarbons compared to the 1.6Pt-NaUSY-im catalyst $\left(C_{4}=41 \%\right.$ and $\left.C_{6}=45 \%\right)$. The predominance of the more selective hydrogenolysis mechanism on the 1.6Pt-NaUSY-im catalyst is tightly related to its milder Brønsted acidity, which does not over-compete with the hydrogenolysis mechanism.

\section{Materials and Methods}

\subsection{Preparation of the Catalysts}

First, a NaUSY zeolite with low density of Brønsted acid sites (BAS) was prepared by submitting a commercial USY sample (CBV760, Si/Al ratio $=27$, Zeolyst International, (Kansas, KS, USA) to four consecutive ion exchanges with $0.1 \mathrm{M} \mathrm{NaNO}_{3}$ aqueous solution (ca. $40 \mathrm{~cm} 3$ per gram of zeolite) at $80^{\circ} \mathrm{C}$ for $8 \mathrm{~h}$ under vigorous stirring. After each ion exchange, the zeolite was filtered off, washed with demineralized water, and dried at $100^{\circ} \mathrm{C}$ for $16 \mathrm{~h}$ (the Na-type USY zeolite obtained was indicated as NaUSY). Then, two xPt-USY-im catalysts with the same Pt loading (denoted by $x$ value, obtained from chemical analysis, ICP-OES) were prepared by incipient wetness impregnation of the pre-dried USY and NaUSY zeolite with an aqueous solution of $\mathrm{H}_{2} \mathrm{PtCl}_{6}$ precursor containing the required platinum amount to achieve nominal Pt contents of $1.5 \mathrm{wt} \%$. To name the catalysts (1.4Pt-USY-im and 1.6Pt-NaUSY-im), the numbers before Pt stand for the metal content of the catalyst, in sequence comes the support which was USY and NaUSY and, finally, comes the method to introduce platinum, viz. -im (incipient wetness impregnation). Both catalysts were calcined in airflow of $140 \mathrm{~mL} /(\mathrm{min} \cdot \mathrm{g})$ at $300{ }^{\circ} \mathrm{C}$ for $2 \mathrm{~h}$ (heating rate of $2{ }^{\circ} \mathrm{C} / \mathrm{min}$ ).

\subsection{Characterization Techniques}

The chemical composition ( $\mathrm{Pt}$ and $\mathrm{Na}$ content, $\mathrm{Si} / \mathrm{Al}$ ratio) of the materials was determined by inductively coupled plasma-optical emission spectrometry (ICP-OES) in a Varian 715-ES spectrometer after the dissolution of the solids in an acid mixture of $\mathrm{HNO}_{3}: \mathrm{HF}: \mathrm{HCl}$ in a 1:1:3 volume ratio.

$X$-ray powder diffraction (XRD) patterns were recorded on a Philips $X^{\prime} P$ Pert diffractometer equipped with a PANanalytical $X^{\prime} C$ elerator detector and using monochromatic $\mathrm{CuK}_{\alpha}$ radiation $\left(\lambda_{1}=0.15406 \mathrm{~nm}\right.$, $\lambda_{2}=0.15444 \mathrm{~nm}, \mathrm{I}_{2} / \mathrm{I}_{1}=0.5$ ). The diffractograms were recorded in the $2 \theta$ range of $2^{\circ}$ to $90^{\circ}$, with a step size of $0.04^{\circ}$ and a scan time of $35 \mathrm{~s}$ per step. Relative crystallinity of NaUSY sample and Pt-NaUSY catalysts was calculated by comparing the area of the diffraction peaks at ca. $2 \theta=20^{\circ}$ and $2 \theta=24^{\circ}$ with that of the commercial USY sample (CBV760, 100\% crystallinity).

Textural properties were derived from the $\mathrm{N}_{2}$ adsorption isotherms measured at $-196^{\circ} \mathrm{C}$ in an ASAP-2000 equipment (Micromeritics). Specific surface areas were calculated following the Brunauer-Emmett-Teller (BET) method and the micropore volume was determined by applying t-plot approach to the adsorption branch of the isotherms. Prior to the adsorption measurements, the samples were degassed at $400{ }^{\circ} \mathrm{C}$ and vacuum overnight. 
The dispersion of platinum in Pt-NaUSY catalysts was determined from $\mathrm{H}_{2}$ chemisorption at $35^{\circ} \mathrm{C}$ using the double isotherm method in a Quantachorme Autosorb-1C equipment (Ashland, Virginia, USA). Prior to adsorption, the samples were reduced in situ in flowing hydrogen at the same reduction conditions applied before catalysis $\left(400{ }^{\circ} \mathrm{C}, 2 \mathrm{~h}\right)$. The Pt dispersion $\left(\mathrm{D}_{\mathrm{Pt}}\right)$ was calculated from the amount of chemisorbed $\mathrm{H}_{2}$ assuming a $\mathrm{Pt}: \mathrm{H}=1$ atomic ratio stoichiometry.

The acid properties of bare supports and Pt-containing catalysts were assessed by FTIR spectroscopy of adsorbed pyridine in a Nicolet 710 FTIR apparatus (Waltham, MA, USA). To this purpose, self-supported wafers at $10 \mathrm{mg} / \mathrm{cm}^{2}$ were prepared and degassed at $400{ }^{\circ} \mathrm{C}$ overnight under dynamic vacuum (10-6 mbar). Then, $1.8 \times 103 \mathrm{~Pa}$ of pyridine were admitted to the IR cell and, after equilibration at room temperature (RT), the samples were degassed at $250{ }^{\circ} \mathrm{C}$, the corresponding spectrum was recorded at RT after each desorption step and the background spectrum subtracted. The concentrations of Brønsted and Lewis acid sites were obtained from the integrated areas of the IR pyridine bands at ca. 1450 and $1545 \mathrm{~cm}^{-1}$, respectively, using the molar extinction coefficients reported by Emeis [30].

\subsection{Catalytic Experiments}

SRO of decalin (a mixture of cis-decalin and trans-decalin, anhydrous $\geq 99 \%$, Sigma-Aldrich, San Luis, Misuri, USA) as model bi-naphthenic feed was carried out in a fixed bed reactor at $\mathrm{T}=300-390^{\circ} \mathrm{C}, \mathrm{P}=3.5 \mathrm{MPa}, \mathrm{WHSV}=0.44 \mathrm{~h}^{-1}$, and $\mathrm{H}_{2} /$ decalin ratio of 100 . In a typical experiment, the reactor was charged with 1.0 of catalyst previously crushed and sieved to a particle size of $0.25-0.42 \mathrm{~mm}$ diameter and diluted with silicon carbide ( $\mathrm{CSi}, 0.59-0.84 \mathrm{~mm}$ particle size) until a constant bed volume of $6.5 \mathrm{~cm}^{3}$. Before starting the reaction, the catalysts were reduced in situ with pure hydrogen $(200 \mathrm{~mL} / \mathrm{min})$ at $400{ }^{\circ} \mathrm{C}\left(1{ }^{\circ} \mathrm{C} / \mathrm{min}\right.$ heating rate) for $2 \mathrm{~h}$ at atmospheric pressure.

Reaction products were regularly analyzed on-line in a gas chromatograph Brucker (Billerica, MA, USA) 450 GC equipped with a capillary column (BR-1 FS, $50 \mathrm{~m} \times 0.25 \mathrm{mn} \times 0.5 \mu \mathrm{m}$ ) and an FID detector. He was used as a carrier gas and the temperature program of the oven was: Isotherm at $40^{\circ} \mathrm{C}$ (10 min), heating to $120^{\circ} \mathrm{C}$ at $5{ }^{\circ} \mathrm{C} / \mathrm{min}$, and then to $200^{\circ} \mathrm{C}$ at $10^{\circ} \mathrm{C} / \mathrm{min}$ with a final isotherm step of $10 \mathrm{~min}$. Decalin conversion, as well as quantification of the different products grouped by carbon atom number, was determined by on-line GC analysis. A mixture of cis-decalin (60 wt $\%)$ and trans-decalin $(40 \mathrm{wt} \%)$ was used as reactive feed, thus decalin conversion was calculated by measuring both isomers unreacted peaks in on-line GC analysis.

Consistent with their carbon atom number, reaction products were grouped as cracking products ( $\mathrm{C}_{9-}$ fraction, cracking/hydrogenolysis products containing less than 10 carbon atoms) and $\mathrm{C}_{10}$ products (isomerization, ring opening, and dehydrogenation products with the same number of carbon atoms than the feed). At the reaction condition studied, products with more than 10 carbon atoms were not detected. According to other authors reports n-nonane retention time was used to separate the $C_{1}-C_{9}$ fraction from $C_{10}$ fraction in on-line GC analysis, owing to the fact that $n$-nonane is the last $C_{9}$ compound to elute from the reaction mixture of decalin ring opening reaction products and to be unambiguous identified [16]. Consequently, yield to $C_{9-}$ products were obtained from the chromatographic areas of the peaks with retention time $\left(t_{R}\right)$ equal to or lower than n-nonane, as it is indicated in Equation (1).

$$
\mathrm{C} 9-=\frac{\sum \text { Area peak } t_{R} \leq \text { nonane }}{\sum \text { Area }_{j}},
$$

where area $_{j}$ is the area of the chromatographic peak corresponding to $j$ product, normalized to $100 \%$ in respect to the total area of the chromatogram.

On the other hand, $\mathrm{C}_{10}$ products' yield was measured from the peak areas with retention time higher than n-nonane, excluding cis-decalin and trans-decalin, as it is indicated in Equation (2).

$$
\mathrm{C} 10=\frac{\sum \text { Area peak }_{R}>\text { nonane }- \text { Area }_{\text {cis-decalin }}-\text { Area }_{\text {tran-decalin }}}{\sum \text { Area }_{j}},
$$


In agreement with other authors reports [25,31], inadequate peak separation was achieved in the $\mathrm{C}_{10}$ chromatogram zone using a GC capillary column, owing the co-elution of the high amount of $\mathrm{C}_{10}$ products obtained by means of decalin conversion over Pt-zeolite catalysts. A deep analysis of this fraction was carried out by comprehensive two-dimensional GC $\times$ GC-MSD technique. With this purpose, reaction products were condensed after on-line GC analysis using a cooling trap held at $-7^{\circ} \mathrm{C}$. These liquid product samples were stored and used for off-line GC $\times$ GC analysis. A bi-dimensional GC $\times$ GC Agilent 7890A chromatograph equipped with both a mass detector Agilent 5977A and a FID was used. Two GC columns, HP-INNOWAX $(30 \mathrm{~m} \times 250 \mu \mathrm{m} \times 0.25 \mu \mathrm{m})$ and a DB-5 $(5 \mathrm{~m} \times 250 \mu \mathrm{m} \times$ $0.25 \mu \mathrm{m})$ were connected in series by means of a flow modulator. The temperature program of the primary oven was: Isotherm at $40^{\circ} \mathrm{C}$ for $20 \mathrm{~min}$, heating to $70^{\circ} \mathrm{C}$ with a heating rate of $1{ }^{\circ} \mathrm{C} / \mathrm{min}$, and afterward to $235^{\circ} \mathrm{C}$ at a heating rate of $4{ }^{\circ} \mathrm{C} / \mathrm{min}$, and maintaining the final temperature for $8.75 \mathrm{~min}$. The second column was placed in an auxiliary oven with the following thermal program: Isotherm at $55^{\circ} \mathrm{C}$ for $1 \mathrm{~min}$, heating to $99.8^{\circ} \mathrm{C}$ with a heating rate of $0.8{ }^{\circ} \mathrm{C} / \mathrm{min}$, and afterward to $235^{\circ} \mathrm{C}$ at a heating rate of $4{ }^{\circ} \mathrm{C} / \mathrm{min}$, and maintaining the final temperature for $9.2 \mathrm{~min}$. Samples of $0.5 \mu \mathrm{L}$ were injected with a split ratio of 100 . Hydrogen carrier flows were $0.3 \mathrm{~mL} / \mathrm{min}$ in the first column and $24 \mathrm{~mL} / \mathrm{min}$ in the second one. The modulation period was $4.5 \mathrm{~s}$. FID temperature was at $300{ }^{\circ} \mathrm{C}$ with an acquisition frequency of $100 \mathrm{~Hz}$. Regarding mass spectroscopy, MS acquisition frequency was set to $14 \mathrm{scans} / \mathrm{s}$ in a mass range of 40 to $360 \mathrm{amu}$.

GC $\times$ GC peaks analyzed with the mass detector allowed the classification of $C_{10}$ products in different families, namely isoD (decalin isomers), ROP (C10-alkylcycloalkanes formed by opening of one decalin ring), OCD (open chain decanes, resulting from the ring opening of ROP), and DHP (dehydrogenated products). GC $\times$ GC peaks analyzed by FID permitted quantification of different family groups. Product distribution in the $\mathrm{C}_{10}$ fraction obtained from GC $\times$ GC analysis was used to calculate overall yields to different groups in the $C_{10}$ fraction from the yield to the products obtained with on-line GC analysis (Equation (2)).

\section{Conclusions}

The investigation of the influence of Bronsted acidity on Pt-USY catalysts was performed by analyzing their effect on the activity and selectivity of these catalysts for the selective ring opening of decalin.

The 1.4Pt-USY-im catalyst presented, predominantly, a reaction mechanism via acid catalysis, while the 1.6Pt-NaUSY-im catalyst presented a catalysis reaction mechanism via the platinum metal sites.

The 1.6Pt-NaUSY-im catalyst showed the best results in terms of yield and selectivity to ring opening products. The maximum yield for OCDs was $14.2 \mathrm{wt} \%$ and the sum of yields for ROPs and OCDs was $28.6 \mathrm{wt} \%$. The respective maximum selectivity for OCDs was $18.7 \mathrm{wt} \%$ and the sum of selectivity for ROPs and OCDs was $37.1 \mathrm{wt} \%$.

A detailed quantitative assessment of $\mathrm{C}_{9-}$ light hydrocarbons formation (cracking) was performed. The 1.4Pt-USY-im catalyst showed an M-type distribution curve in the range $C_{3}$ to $C_{7}$, with maximums at $\mathrm{C}_{4}$ and $\mathrm{C}_{6}$, indicating that the main ring opening reaction mechanism of this catalyst is via beta-scission at Brønsted acid sites, where the paring reaction for ring opening products is characteristic. The 1.6Pt-NaUSY-im catalyst presented a typical hydrogenolysis distribution curve at platinum metal sites with relevant amounts of $C_{9}$, indicating that the decalin ring opening mechanism via platinum sites is the main mechanism for this catalyst.

Author Contributions: Conceptualization, L.W.O.S. and S.B.C.P.; Methodology, L.W.O.S. and S.B.C.P.; Validation, L.W.O.S.; Formal Analysis, L.W.O.S.; Investigation, L.W.O.S. and S.B.C.P.; Resources, L.W.O.S. and S.B.C.P.; Data Curation, L.W.O.S; Writing-Original Draft Preparation, L.W.O.S.; Writing-Review \& Editing, S.B.C.P.

Funding: This research was funded by CNPq via project $n^{\circ} 401474$ (PVE2014).

Acknowledgments: Lech acknowledges the scholarship received by CAPES and CNPq.

Conflicts of Interest: The authors declare no conflicts of interest. 


\section{References}

1. Martínez, A.; Arribas, M.A.; Pergher, S.B.C. Bifunctional noble metal/zeolite catalysts for upgrading low-quality diesel fractions via selective opening of naphthenic rings. Catal. Sci. Technol. 2016, 6, $2528-2542$. [CrossRef]

2. McVicker, G.B.; Touvelle, M.S.; Hudson, C.W.; Vaughan, D.E.W.; Daage, M.; Hantzer, S.; Klein, D.P.; Ellis, E.S.; Cook, B.R.; Feeley, O.C.; et al. Process for Selectively Opening Naphthenic Rings. U.S. Patent 5,763,731, 9 June 1998.

3. McVicker, G.B.; Daage, M.; Touvelle, M.S.; Hudson, C.W.; Klein, D.P.; Baird, W.C., Jr.; Cook, B.R.; Chen, J.G.; Hantzer, S.; Vaughan, D.E.W.; et al. Selective Ring Opening of Naphthenic Molecules. J. Catal. 2002, 210, 137-148. [CrossRef]

4. Kubička, D.; Kumar, N.; Mäki-Arvela, P.; Tiitta, M.; Niemi, V.; Salmi, T.; Murzin, D.Y. Ring opening of decalin over zeolites: I. Activity and selectivity of proton-form zeolites. J. Catal. 2004, 222, 65-79.

5. Santikunaporn, M.; Herrera, J.E.; Jongpatiwut, S.; Resasco, D.E.; Alvarez, W.E.; Sughrue, E.L. Ring opening of decalin and tetralin on HY and Pt/HY zeolite catalysts. J. Catal. 2004, 228, 100-113. [CrossRef]

6. Arribas, M.A.A.; Concepción, P.; Martínez, A.N. The role of metal sites during the coupled hydrogenation and ring opening of tetralin on bifunctional Pt(Ir)/USY catalysts. Appl. Catal. A Gen. 2004, 267, 111-119. [CrossRef]

7. Moraes, R.; Thomas, K.; Thomas, S.; Donk, S.V.; Grasso, G.; Gilson, J.-P.; Houalla, M. Ring opening of decalin and methylcyclohexane over alumina-based monofunctional $\mathrm{WO}_{3} / \mathrm{Al}_{2} \mathrm{O}_{3}$ and $\mathrm{Ir} / \mathrm{Al}_{2} \mathrm{O}_{3}$ catalysts. J. Catal. 2012, 286, 62-77. [CrossRef]

8. Gault, F.G. Mechanisms of Skeletal Isomerization of Hydrocarbons on Metals. In Advances in Catalysis; Eley, D.D., Pines, H., Weisz, P.B., Eds.; Academic Press: Cambridge, MA, USA, 1981; pp. 1-95.

9. Santi, D.; Holl, T.; Calemma, V.; Weitkamp, J. High-performance ring-opening catalysts based on iridium-containing zeolite Beta in the hydroconversion of decalin. Appl. Catal. A Gen. 2013, 455, 46-57. [CrossRef]

10. Djeddi, A.; Fechete, I.; Garin, F. Selective ring opening of methylcyclopentane over $\mathrm{Pt} / \gamma-\mathrm{Al}_{2} \mathrm{O}_{3}, \mathrm{Ir} / \gamma-\mathrm{Al}_{2} \mathrm{O}_{3}$ and $\mathrm{Pt}-\mathrm{Ir} / \gamma-\mathrm{Al}_{2} \mathrm{O}_{3}$ catalysts with hydrogen at atmospheric pressure. Appl. Catal. A Gen. 2012, 413-414, 340-349. [CrossRef]

11. Galperin, L.B.; Bricker, J.C.; Holmgren, J.R. Effect of support acid-Basic properties on activity and selectivity of Pt catalysts in reaction of methylcyclopentane ring opening. Appl. Catal. A Gen. 2003, 239, $297-304$. [CrossRef]

12. Onyestyák, G.; Pál-Borbély, G.; Beyer, H.K. Cyclohexane conversion over H-zeolite supported platinum. Appl. Catal. A Gen. 2002, 229, 65-74.

13. D'Ippolito, S.A.; Benitez, V.M.; Reyes, P.; Rangel, M.C.; Pieck, C.L. Selective ring opening of decalin with $\mathrm{Pt}-\mathrm{Ir} / \mathrm{Al}_{2} \mathrm{O}_{3}$ catalyst prepared by catalytic reduction. Catal. Today 2011, 172, 177-182. [CrossRef]

14. Lecarpentier, S.; van Gestel, J.; Thomas, K.; Gilson, J.-P.; Houalla, M. Study of $\mathrm{Ir} / \mathrm{WO}_{3} / \mathrm{ZrO}_{2}-\mathrm{SiO}_{2}$ ring-opening catalysts: Part II. Reaction network, kinetic studies and structure-activity correlation. J. Catal. 2008, 254, 49-63. [CrossRef]

15. Santikunaporn, M.; Alvarez, W.E.; Resasco, D.E. Ring contraction and selective ring opening of naphthenic molecules for octane number improvement. Appl. Catal. A Gen. 2007, 325, 175-187. [CrossRef]

16. Di Felice, L.; Catherin, N.; Piccolo, L.; Laurenti, D.; Blanco, E.; Leclerc, E.; Geantet, C.; Calemma, V. Decalin ring opening over $\mathrm{NiWS} / \mathrm{SiO}_{2}-\mathrm{Al}_{2} \mathrm{O}_{3}$ catalysts in the presence of $\mathrm{H}_{2}$ S. Appl. Catal. A Gen. 2016, 512, 43-51. [CrossRef]

17. Nassreddine, S.; Massin, L.; Aouine, M.; Geantet, C.; Piccolo, L. Thiotolerant $\mathrm{Ir} / \mathrm{SiO}_{2}-\mathrm{Al}_{2} \mathrm{O}_{3}$ bifunctional catalysts: Effect of metal-acid site balance on tetralin hydroconversion. J. Catal. 2011, 278, 253-265. [CrossRef]

18. Nassreddine, S.; Massin, L.; Aouine, M.; Geantet, C.; Piccolo, L. Thiotolerant $\mathrm{Ir} / \mathrm{SiO}_{2}-\mathrm{Al}_{2} \mathrm{O}_{3}$ bifunctional catalysts: Effect of support acidity on tetralin hydroconversion. Catal. Sci. Technol. 2011, 1, 408-412. [CrossRef]

19. Piccolo, L.; Nassreddine, S.; Toussaint, G.; Geantet, C. Mechanism of Tetralin Ring Opening and Contraction over Bifunctional $\mathrm{Ir} / \mathrm{SiO}_{2}-\mathrm{Al}_{2} \mathrm{O}_{3}$ Catalysts. ChemSusChem 2012, 5, 1717-1723. [CrossRef]

20. Corma, A.; González-Alfaro, V.; Orchillés, A.V. Decalin and Tetralin as Probe Molecules for Cracking and Hydrotreating the Light Cycle Oil. J. Catal. 2001, 200, 34-44. [CrossRef] 
21. Haas, A.; Rabl, S.; Ferrari, M.; Calemma, V.; Weitkamp, J. Ring opening of decalin via hydrogenolysis on Ir/-and Pt/silica catalysts. Appl. Catal. A Gen. 2012, 425-426, 97-109. [CrossRef]

22. Kubička, D.; Kangas, M.; Kumar, N.; Tiitta, M.; Lindblad, M.; Murzin, D.Y. Ring Opening of Decalin Over Zeolite-Supported Iridium Catalysts. Top. Catal. 2010, 53, 1438-1445. [CrossRef]

23. Kumar, N.; Mäki-Arvela, P.; Musakka, N.; Kubicka, D.; Kangas, M.; Tiitta, M.; Österholm, H.; Leino, A.-R.; Kordás, K.; Heikkilä, T.; et al. On the way to improve cetane number in diesel fuels: Ring opening of decalin over Ir-modified embedded mesoporous materials. Catal. Ind. 2013, 5, 105-122. [CrossRef]

24. Ma, H.; Yang, X.; Wen, G.; Tian, G.; Wang, L.; Xu, Y.; Wang, B.; Tian, Z. Coupledhydrogenation and ring opening of tetralin on potassium modified Pt/USY catalysts. Catal. Lett. 2007, 116, 149-154. [CrossRef]

25. Rabl, S.; Haas, A.; Santi, D.; Flego, C.; Ferrari, M.; Calemma, V.; Weitkamp, J. Ring opening of cis-decalin on bifunctional Ir/- and Pt/La-X zeolite catalysts. Appl. Catal. A Gen. 2011, 400, 131-141. [CrossRef]

26. Arribas, M.A.; Corma, A.; Díaz-Cabañas, M.J.; Martínez, A. Hydrogenation and ring opening of Tetralin over bifunctional catalysts based on the new ITQ-21 zeolite. Appl. Catal. A Gen. 2004, 273, 277-286. [CrossRef]

27. Arribas, M.A.; Martínez, A. Production of high cetane diesel fuels by simultaneous hydrogenation of aromatics and ring opening of naphthenes over bifunctional molecular sieves based catalysts. In Studies in Surface Science and Catalysis; Corma, A., Melo, F.V., Mendioroz, S., Fierro, J.L.G., Eds.; Elsevier: Amsterdam, The Netherlands, 2000; pp. 2585-2590.

28. Piccolo, L.; Gigantiello, N.; Parker, W.O.; Calemma, V., Jr. Discussion on “A comprehensive two-dimensional gas chromatography coupled with quadrupole mass spectrometry approach for identification of C10 derivatives from decalin" by C. Flego, N. Gigantiello, WO Parker, Jr., V. Calemma [J. Chromatogr. A 1216 (2009) 2891]. J. Chromatogr. A 2010, 1217, 5872-5873. [PubMed]

29. Blanco, E.; Felice, L.D.; Catherin, N.; Piccolo, L.; Laurenti, D.; Lorentz, C.; Geantet, C.; Calemma, V. Understanding the Mechanisms of Decalin Hydroprocessing Using Comprehensive Two-Dimensional Chromatography. Ind. Eng. Chem. Res. 2016, 55, 12516-12523. [CrossRef]

30. Emeis, C.A. Determination of Integrated Molar Extinction Coefficients for Infrared Absorption Bands of Pyridine Adsorbed on Solid Acid Catalysts. J. Catal. 1993, 141, 347-354. [CrossRef]

31. Flego, C.; Gigantiello, N.; Parker, W.O.; Calemma, V., Jr. A comprehensive two-dimensional gas chromatography coupled with quadrupole mass spectrometry approach for identification of C10 derivatives from decalin. J. Chromatogr. A 2009, 1216, 2891-2899. [CrossRef] [PubMed] 